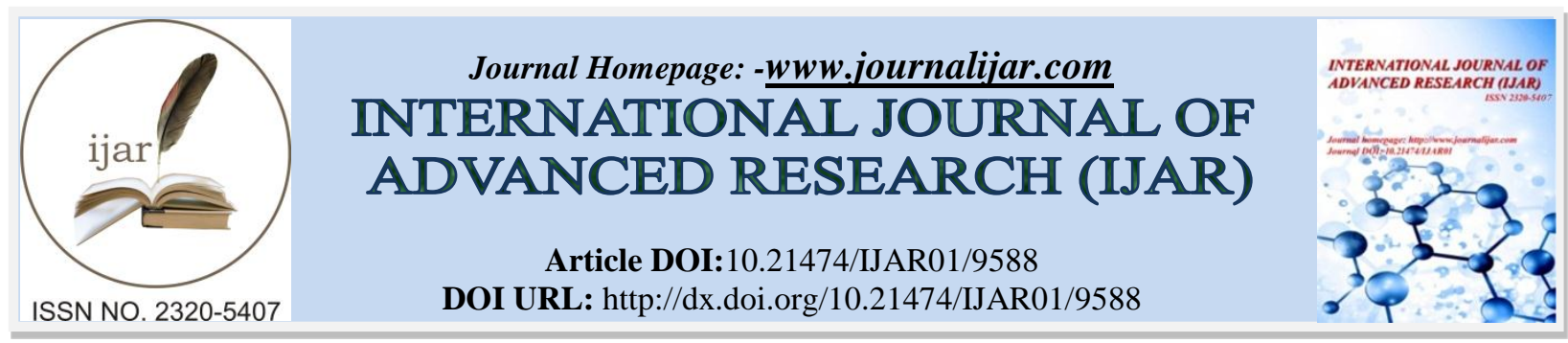

RESEARCH ARTICLE

\title{
POST BURN CONTRACTURE OF NECK A CLINICAL STUDY.
}

\author{
Dr.K.V.N.Prasad. \\ MS.MCh(Plastic Surgery),AsstProfessor,Dept of Plastic Surgery, Kurnool Medical College,Kurnool,AP,INDIA.
}

\section{Manuscript Info}

Manuscript History

Received: 18 June 2019

Final Accepted: 20 July 2019

Published: August 2019

\begin{abstract}
In India after deregulation of insurance sector, there was a large change in insurance business, their products and services offered to the clients. This insurance sector also plays a remarkable role in the advancement of a country's economy. From many previous study shows that insurance spread is extremely thin in India. Though, many research studies has not attempted to expose the reason why the insurance services were not purchasing or used by the local people especially the unreached areas. This paper will inquire about to fill up this gap. Therefore, this study provides a brief analysis of obstacles faced by the insurance services providers in terms of before opening an insurance branch to unreached areas and their services delivery to the clients in Manipur. This study also has identified the dependable factors for escalating the cost of penetration to unreached areas.
\end{abstract}

Copy Right, IJAR, 2019,. All rights reserved.

\section{Introduction:-}

Post burn contracture continues to be a problem in plastic and reconstructive surgery. After release of the contracture the resulting raw area needs a suitable covering. The conventional methods range from the use of splitthickness skin graft, local manipulation of tissue by advancement, transposition, fasciocutaneous, myocutaneous flaps and free micro vascular flap. VAC assisted closure or reduction of the wound coupled with use of artificial dermis is reported Tissue expander to generate more local skin also has its role.

\section{Aim Of The Study}

1. To assess the extent of restoration of Cervico-Mental angle \& the range of cervical movements

2. To assess the compliance of patients in usage of splint

3. To assess the complications in patients while undergoing surgery \& post-operatively

4. To study the Re-Contracture rate \& redo surgery.

\section{Materials And Methods:-}

Twenty patients with established contracture following flame burns and Chemical burns were selected.

This study aims at determining the degree of movements at the neck after release and resurfacing the defect with split thickness skin graft in post burn contracture of neck. Twenty consecutive patients with established post burn contracture of neck were selected for the study. All were operated where the contractures were released by complete scar excision combined with designing local flaps to interrupt straight line scars. Resurfacing was done with split thickness skin grafts (SSG) in eighteen patients and Full thickness graft (FTG) in two patients. Post operative follow

Corresponding Author:-Dr.PS.RajaRavi Kumar

Address:-MS.MCh(Plastic Surgery),AsstProfessor,Dept of Plastic Surgery, Kurnool Medical College,Kurnool,AP,INDIA. 
up was done in twelve patients after twelve months to measure the degree of extension in antero-posterior and lateral direction.

\section{Procedure}

1 Extent of skin required was estimated by measuring from a normal person of similar build and a template was made and sterilized.

2 Patient was anesthetized by suitable mode planned pre-operatively, put on supine position with neck extended as much as possible within limit of the contracture. Neck, face, upper chest and donor area were prepared and drapped.

3 The area to be excised was infiltrated with Tumescent fluid .This would ease the dissection and minimize bleeding.

4 Complete excision of the scar was done. The scars extending over the mandible was excised. This corrected the pull over the lips also. When scar was extending over the upper chest it was totally excised. When the chest involvement was extending below the clavicle and involved lower chest and abdomen the scar was excised as much as possible with plans to repeat the procedure at a later date. On each side of the neck the vertical margins of the wound were interrupted with Z-plasties of unequal lengths where one of the arms was transposed and the other arm was formed with skin graft. The chin-neck angle was made as much near 90 degrees as possible. Fish mouth cuts were made at suitable intervals to avoid a straight line and also to ensure complete release. These areas were to be fed with skin during covering the area.

5 After a satisfactory release of the neck a careful hemostasis was secured and the field made dry off any oozing.

6 A good thick sheet of split thickness skin graft was harvested. The donor area was dressed conventionally

7 The graft was fixed to the defect edges using tie-over method, taking care to feed the graft into the small triangular defects following release incisions. If the graft was in pieces, care was taken to place the junction line horizontally and avoid a vertical line to prevent recurrence of contracture.

8 Any air bubble or collections were teased out from the bed so as to ensure close contact between the graft and the bed.

9 Tie-over dressing:-A layer of sofratulle was spread over the graft, packed with multiple layers of wet cotton squeezed dry to build a convex surface and the suture ends that were left long were tied over this dressing. A bulky dressing of dry gamgee pads were reinforced over this and secured with adhesive tapes.

10 In our series a soft cervical collar initially followed by a hard collar served the purpose of effective splintage.

11 Patient was extubated under supervision as to not to disturb the dressing. An extended neck position was maintained post operatively

12 A constant watch was kept for development of breathing problems, vomiting and oozing. Mild sedation and analgesics and an empirical mild antibiotics were administered.

13 On the $5^{\text {th }}$ post operative day, the dressing was inspected, tie over dressing opened and long sutures removed. Cervical collar was re-applied.

14 After $10^{\text {th }}$ post-operative day a light lubricant massage was given to the graft and advised to repeat the same by the patient.

15 The splint was wor $\mathrm{n}$ continuously day and night for about six months. Periodic inspection of the graft was made to look for any wrinkling. Once the graft settled, soft and supple, usually six months, the splint was discarded.

\section{Results:-}

Twenty patients with established post burn contracture of neck were selected for this study. There were 1023 patients admitted in the department of Plastic Surgery. Thus neck contracture constituted 4\% of Plastic surgery admissions in our department.

Table 1:-Magnitude of the problem

\begin{tabular}{|l|l|}
\hline No. of admissions & 1023 \\
\hline Neck involved & 40 \\
\hline
\end{tabular}




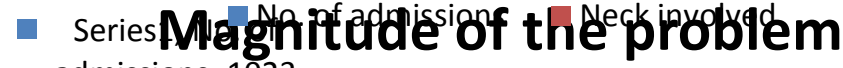 admissions, 1023}

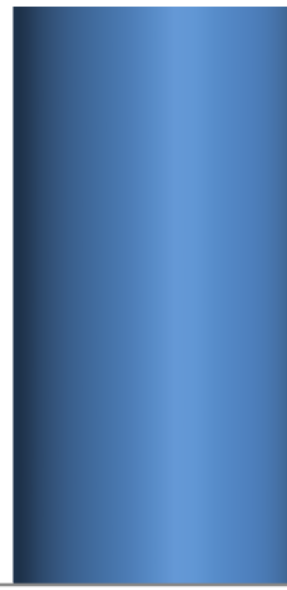

Series1, Neck

involved , 40

There were eleven male and nine female patients, with 4 children below fifteen years.

Table 2:-Sex ratio in the series

\begin{tabular}{|c|c|c|c|}
\hline Male & Female & Total & Ratio \\
\hline 11 & 9 & 20 & $1: 1$ \\
\hline
\end{tabular}

Nineteen patients had contractures of the neck following flame burns and one patient had chemical burn with acid.

The disability due to contracture varied from mild restriction of flexion and extension fig to "frozen neck" meaning complete restriction of flexion and lateral rotation ${ }^{\text {fig }}$

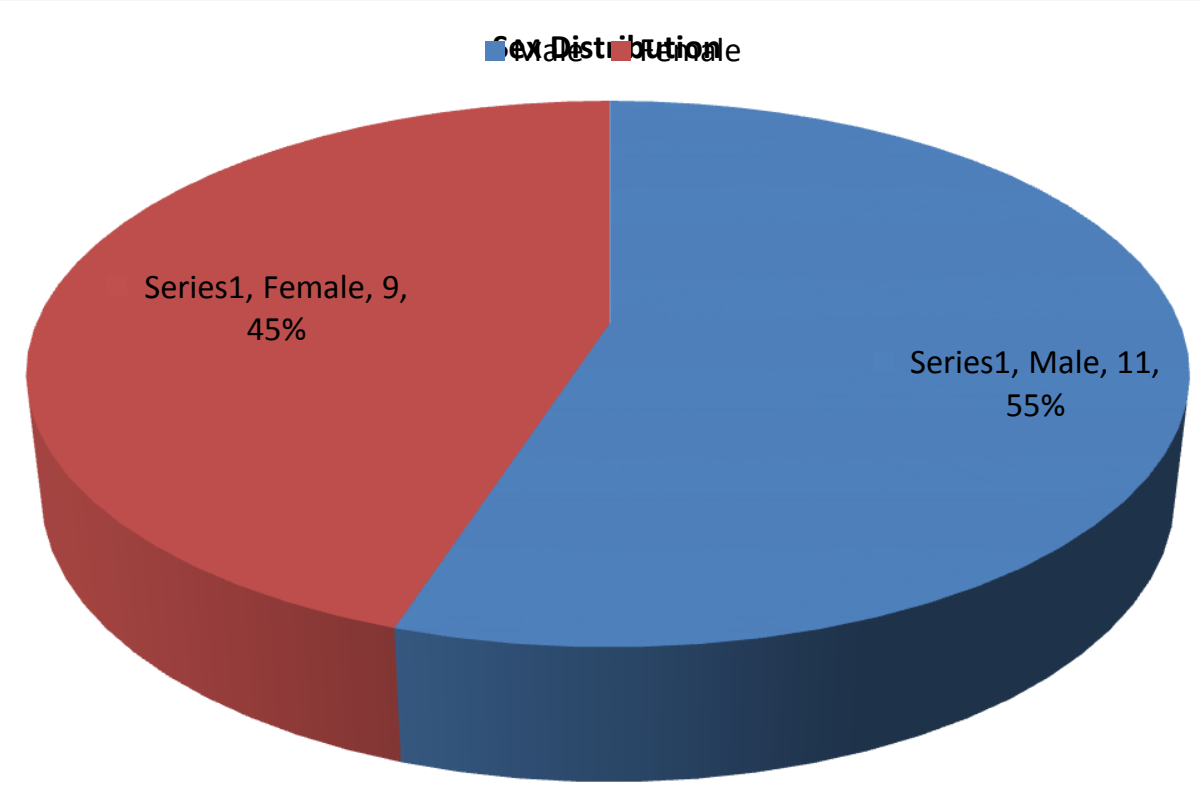


Tables 3:

All these patients were treated with split thickness skin graft supplemented with local flaps to break the line of scar.

Two patients received full thickness graft.

Table 3:-Extent of contracture neck

\begin{tabular}{|l|l|l|l|l|l|}
\hline Complete & Partial & procedure & number & $\begin{array}{l}\text { Result in } \\
\text { terms } \\
\text { take }\end{array}$ & $\begin{array}{l}\text { Range of motion } \\
\text { after 6 months }\end{array}$ \\
\hline 10 & 10 & SSG & 17 & $96 \%$ & $90 \%$ \\
& & Z-Assisted SSG & 1 & $96 \%$ & $100 \%$ \\
& FTG & 2 & $96 \%$ & $100 \%$ \\
\hline
\end{tabular}

Table No 4:-Skin resurfacing and graft take

\begin{tabular}{|l|l|l|l|l|}
\hline \multicolumn{1}{|c|}{ No } & initials & procedure & Graft take & Remark \\
\hline 1 & GI & SSG & $80 \%$ & Graft loss needed re graft \\
\hline 2 & SA & SSG & $75 \%$ & Graft loss needed re graft \\
\hline 4 & JA & SSG & $98 \%$ & Nil \\
\hline 5 & GO & SSG & $95 \%$ & Nil \\
\hline 6 & VA & FTG & $100 \%$ & Nil \\
\hline 7 & SA & SSG & $96 \%$ & Nil \\
\hline 8 & SO & SSG & $98 \%$ & Nil \\
\hline 9 & RE & FTG & $99 \%$ & Nil \\
\hline 10 & VE & SSG & $98 \%$ & Nil \\
\hline 11 & BA & SSG & $100 \%$ & Nil \\
\hline 12 & AN & SSG & $95 \%$ & Nil \\
\hline 13 & SH & SSG & $99 \%$ & Nil \\
\hline 14 & BA & SSG & $97 \%$ & Nil \\
\hline 15 & KR & Zplasty and SSG & $98 \%$ & Nil \\
\hline 16 & UM & SSG & $98 \%$ & Nil \\
\hline 17 & SR & SSG & $75 \%$ & Nil \\
\hline 18 & RU & SSG & $99 \%$ & Graft loss needed \\
\hline 19 & PA & SSG graft & Nil \\
\hline 20 & SA & $98 \%$ & Nil \\
\hline
\end{tabular}

Table 5:-Degree of neck movements

\begin{tabular}{|c|c|c|c|c|c|c|c|}
\hline \multirow{2}{*}{$\begin{array}{l}\begin{array}{l}\text { Patient } \\
\text { Number/ name }\end{array} \\
\text { S no/ pat. No. } \\
\end{array}$} & \multicolumn{2}{|c|}{$\begin{array}{l}\text { Anterior flexion } \\
\text { Chin-sternum cms }\end{array}$} & \multicolumn{2}{|c|}{$\begin{array}{l}\text { Right lateral } \\
\text { Chin to Rt shoulder } \\
\text { cms }\end{array}$} & \multicolumn{2}{|c|}{$\begin{array}{l}\text { Left lateral } \\
\text { Chin, Lt, shoulder } \\
\text { cms }\end{array}$} & \\
\hline & Pre-op & Post-op & Pre-op & Post-op & Pre-op & Post-op & \\
\hline 1/1 Giribabu & 3 & 13 & 21 & 12 & 21 & 13 & $80 \%$ \\
\hline $2 / 2 \quad$ Satish & 6 & 12 & 21 & 15 & 21 & 14 & $70 \%$ \\
\hline 3/3 Jagannath & 8 & 15 & 21 & 7 & 21 & 9 & $80 \%$ \\
\hline 4/5 varalakshmi & 13 & 15 & 21 & 21 & 19 & 4 & $90 \%$ \\
\hline 5/7 $\quad$ Padmavathi & 10 & 13 & 16 & 5 & 7 & 5 & $90 \%$ \\
\hline 6/8 $\quad$ Shoba & 10 & 14 & 8 & 3 & 9 & 5 & $90 \%$ \\
\hline 7/9 $\quad$ Renuka & 9 & 12 & 17 & 14 & 17 & 17 & $95 \%$ \\
\hline 8/11 Bagyalaxmi & 1 & 12 & 20 & 16 & 20 & 16 & $70 \%$ \\
\hline 9/13 Shankar & 3 & 14 & 15 & 4 & 14 & 3 & $98 \%$ \\
\hline 10/15 krishnayya & 10 & 12 & 14 & 12 & 14 & 13 & $98 \%$ \\
\hline 11/16 Uma & 12 & 15 & 20 & 20 & 20 & 20 & $100 \%$ \\
\hline $12 / 17 \quad$ Sriveni & 0 & 13 & 16 & 5 & 16 & 6 & $80 \%$ \\
\hline 13/19 Maramma & 6 & 13 & 21 & 9 & 21 & 8 & $90 \%$ \\
\hline
\end{tabular}




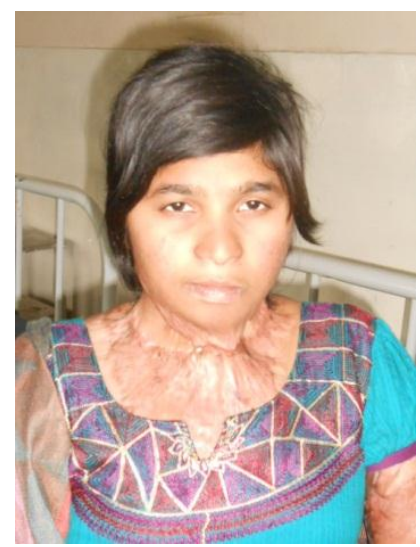

Preoperative

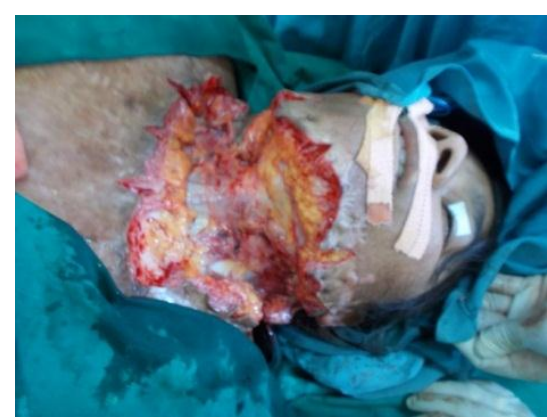

Intraoperative

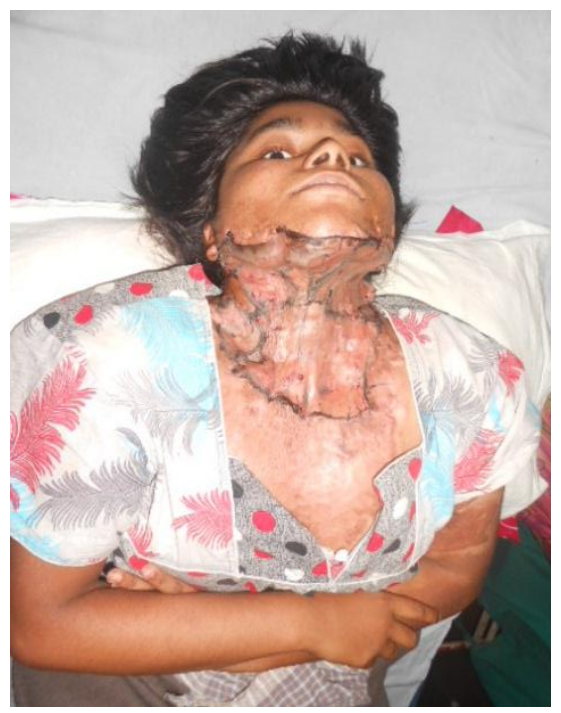

Postoperative 


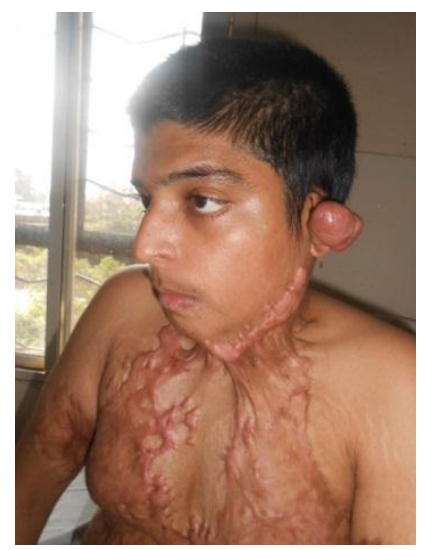

Preoperative

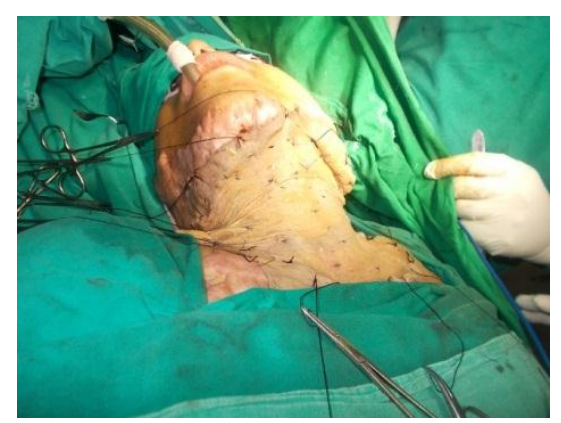

Intraoperative

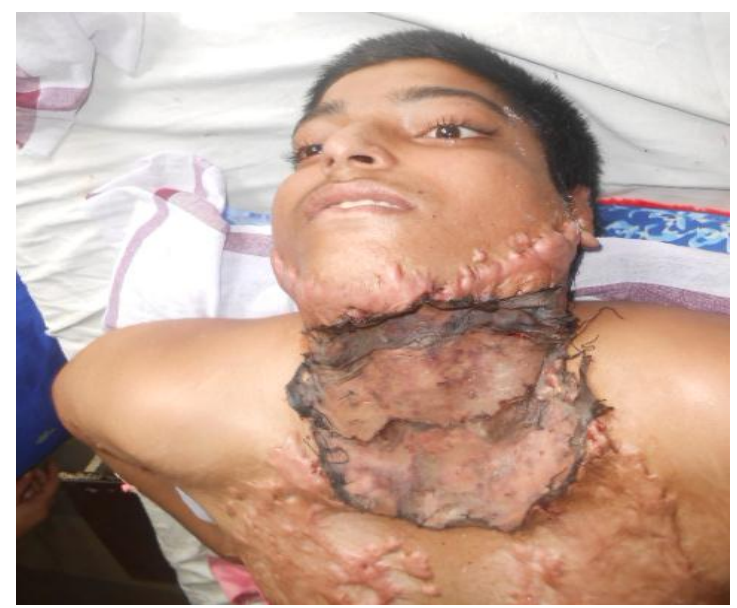

Postoperative 


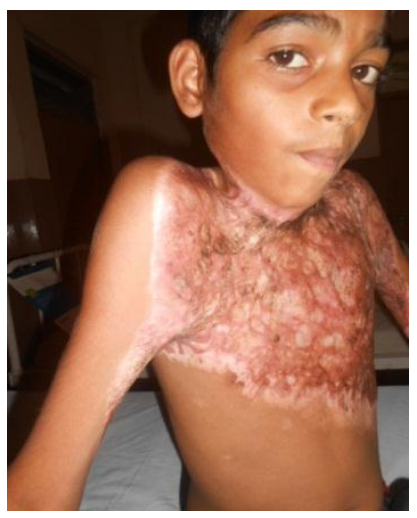

Pre0perative

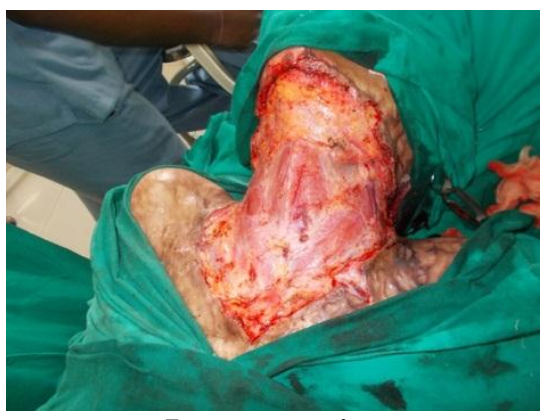

Intraoperative

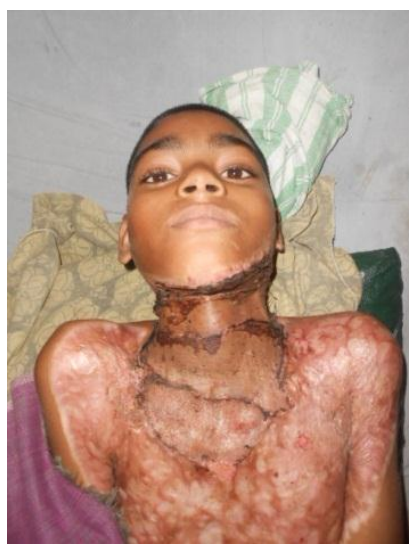

Postoperative 


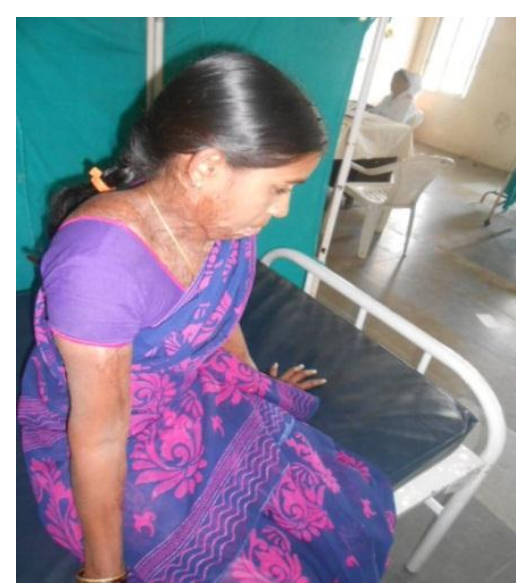

Preoperative

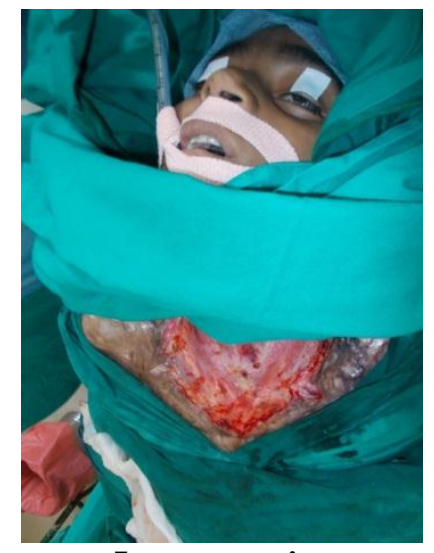

Intraoperative

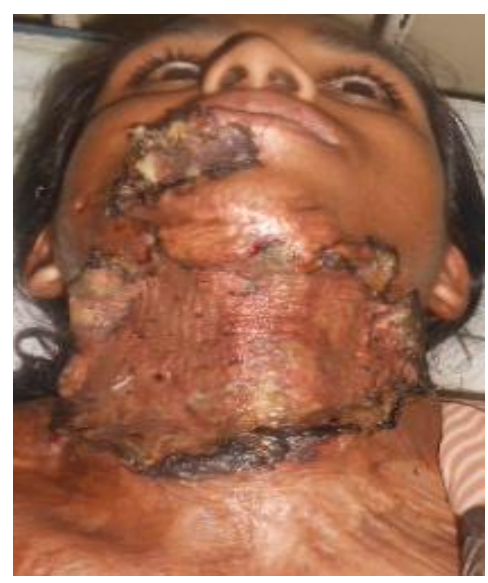

Postoperative 

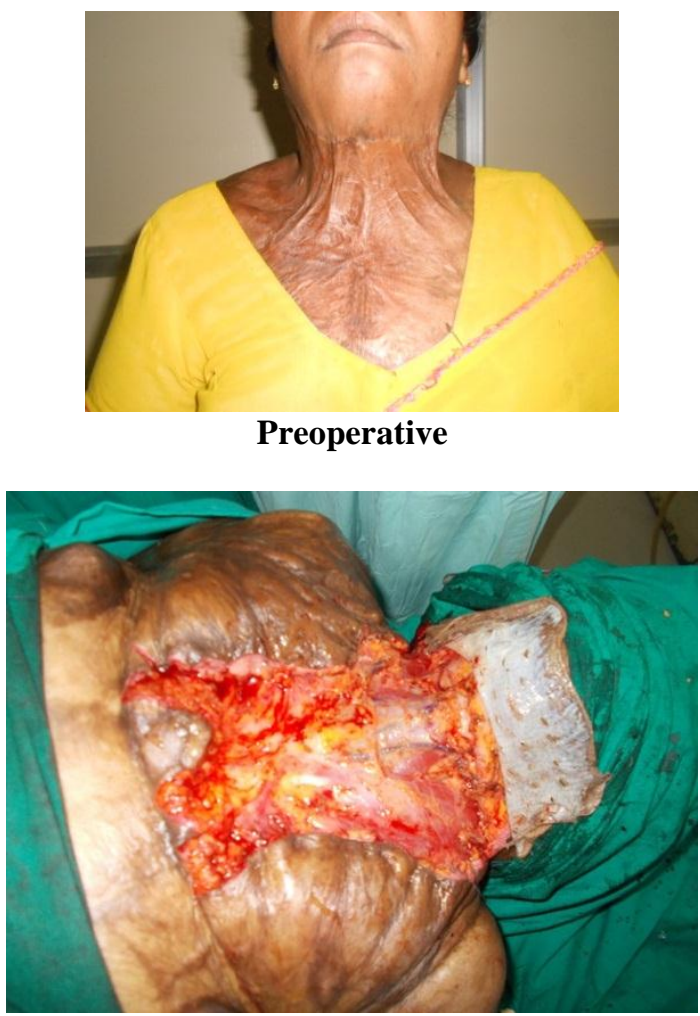

Intraoperative

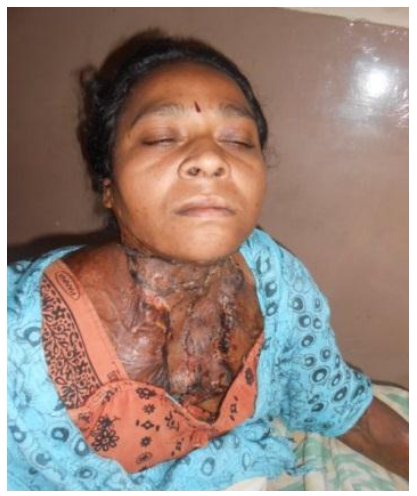

Postoperative

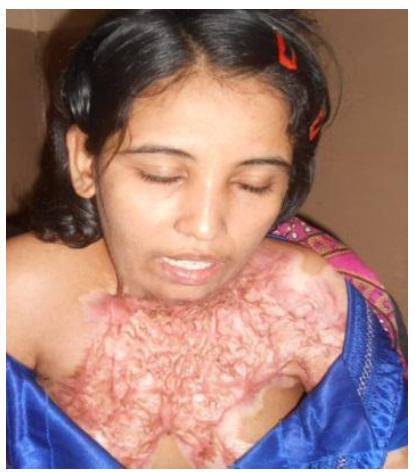

Preoperative 


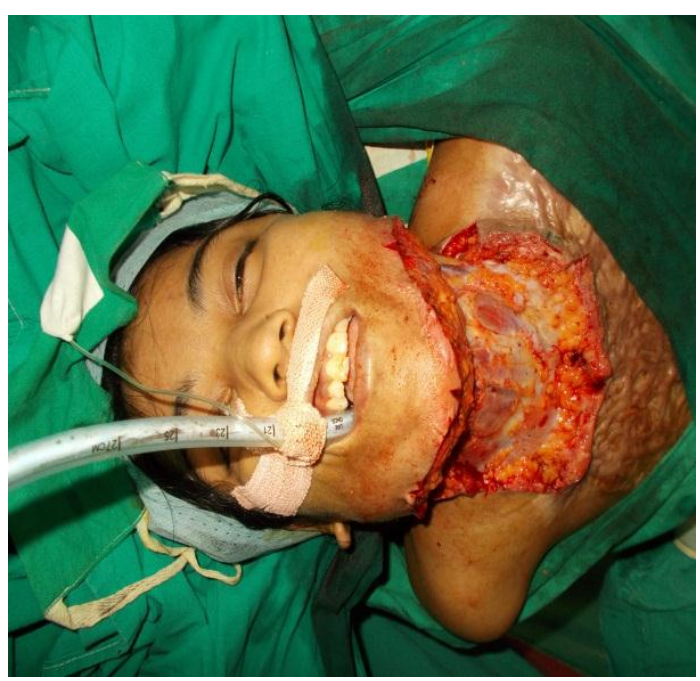

Intraoperative

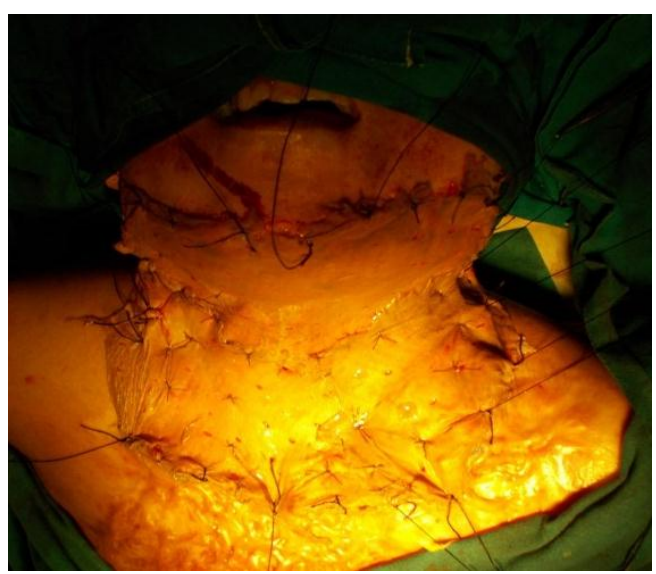

Postoperative

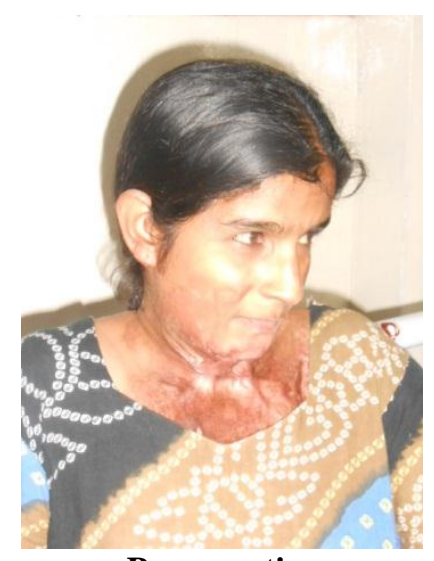

Preoperative 


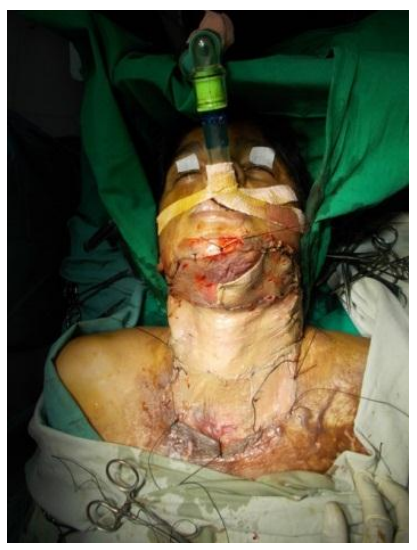

Intraoperative

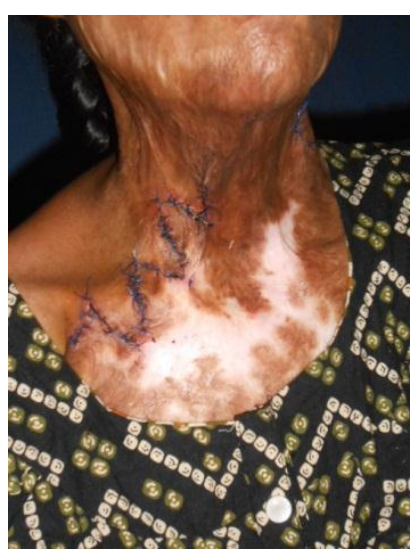

Postoperative

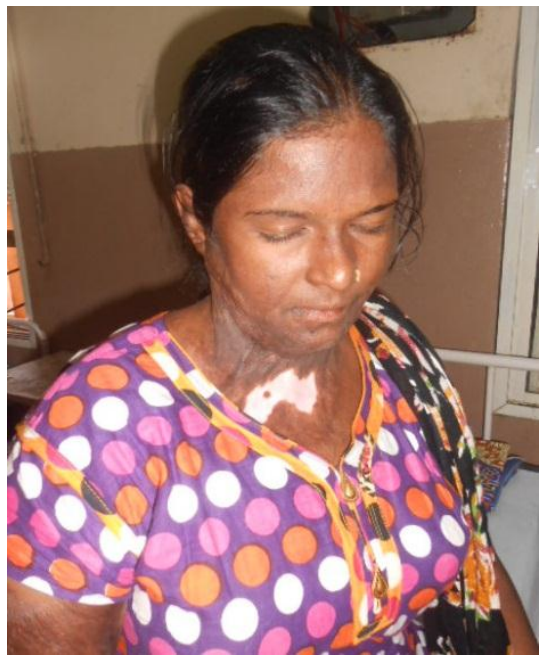

Preoperative 


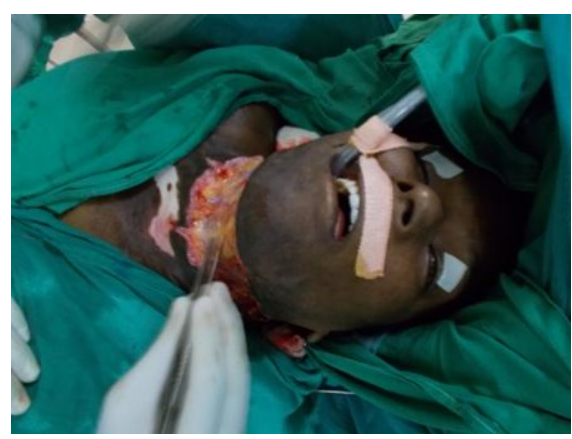

Intraoperative

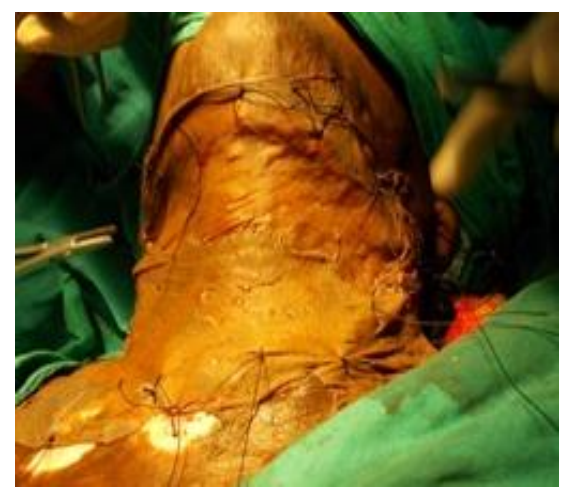

Postoperative

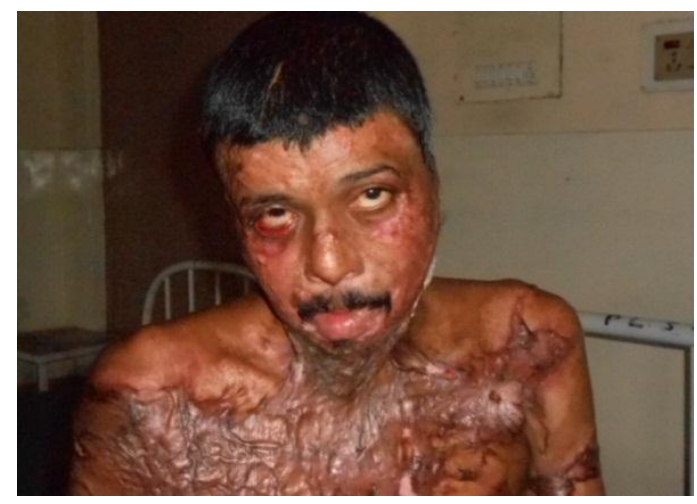

Preoperative

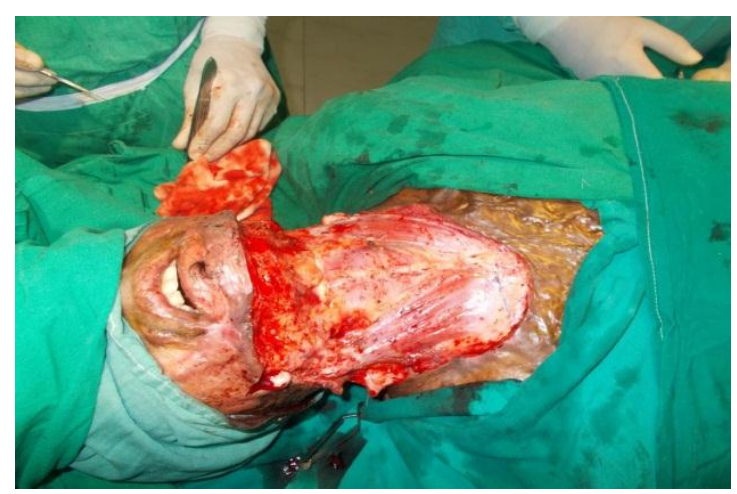

Intraoperative 


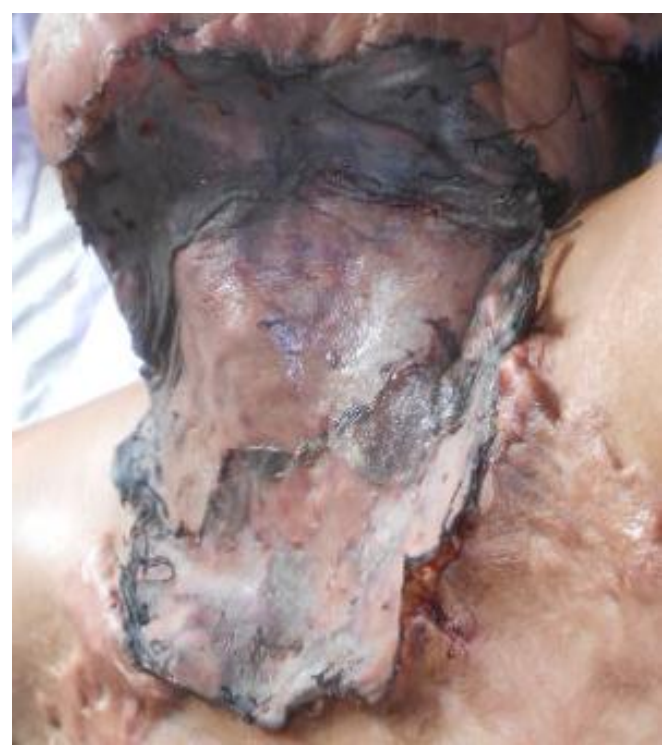

Postoperative

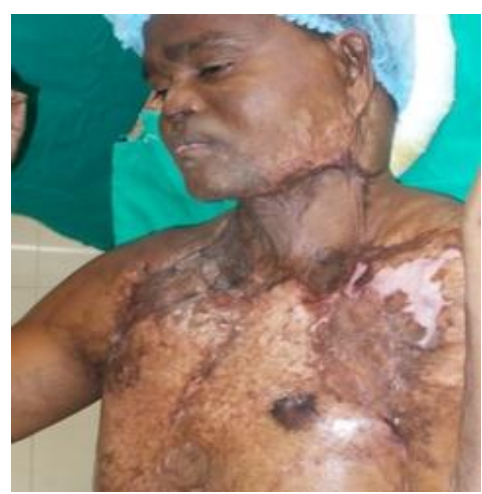

Preoperative

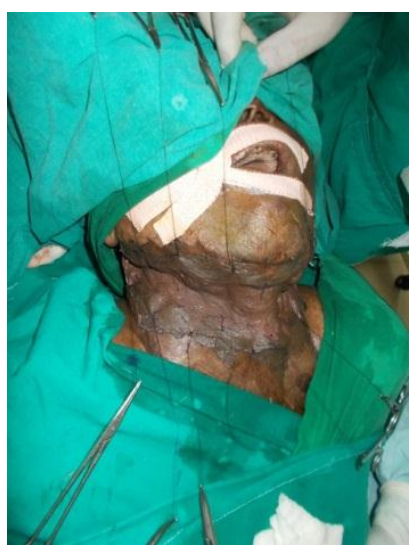

Intraoperative 


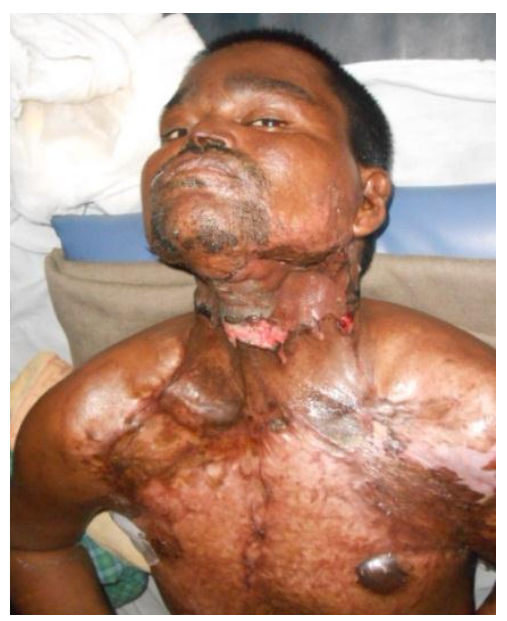

Postoperative

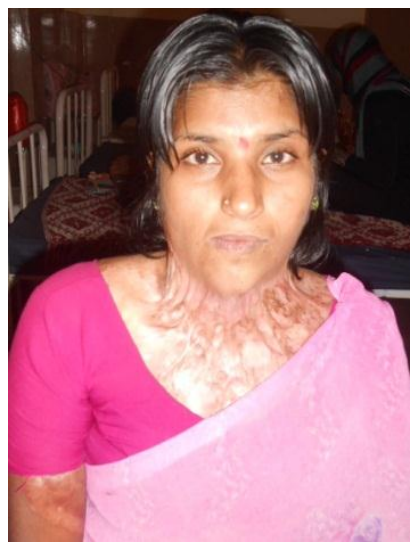

Preoperative

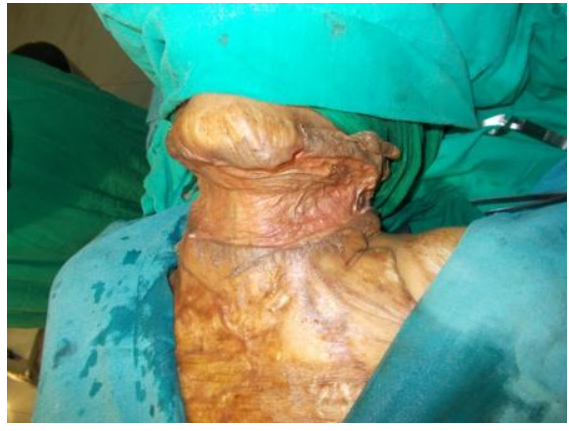

Intraoperative 


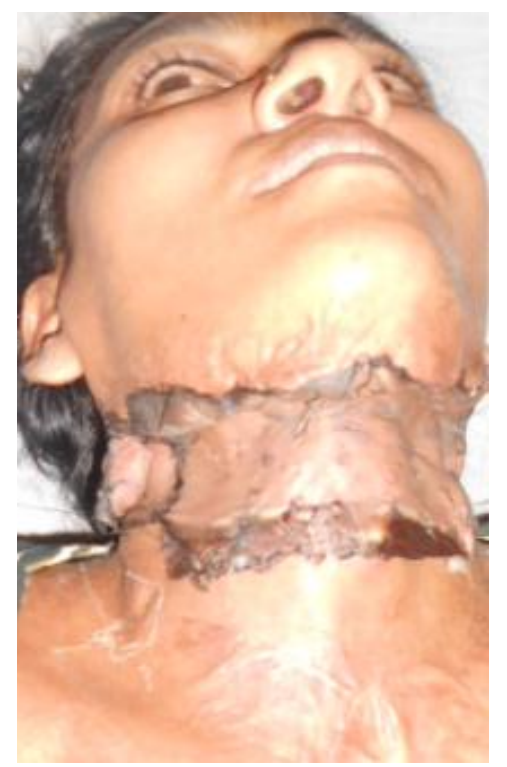

\section{Postoperative}

\section{Discussion:-}

The post burn contracture of the neck is a common problem encountered in any unit treating Burns. The neck is a cylindrical structure with a concavity anteriorly and the flexor surface connecting the chin to the sternum. It has a thin skin likely to get destroyed easily. The neck is often given less attention in the initial phase of treatment of severe burns where saving life takes the priority. All these factors put together makes the neck undergo contractures and pose a great problem to the patient and surgeon. Our series records a (4\%) burns affecting the neck out of 1023 total plastic surgical admissions.

Most scar contractures of the neck result from thermal burns . Other causes are chemical burns, electrical burns and radiation, and vertical scars. In our series nineteen patients had flame burns and one chemical burn (acid) as the cause of neck contracture.

Surgical treatment of an established post-burn neck contracture includes problems of anaesthesia, contracture release, skin grafting, splintage and maintenance of the fully release state.

The proper treatment of severe contractures of the neck has been a challenging task to the surgeon and a trying situation for the patient. Many authorities have recommended skin flaps Full thickness skin grafts are advocated as they are thin and match the delicate skin of the neck and graft contractures and wrinkling are minimum . In patients with multiple area and extensive burns getting adequate donor site to obtain a big sheet of full thickness graft poses a problem. Scrupulous hemostasis and immobilization are basic need for a good take of this graft. This series records two patients with FTG; both had $96 \%$ take and final functional result was good and the cosmetic appeal was excellent.

A combination of a strip of flap below the mandible and a thick skin graft below is advised ${ }^{37}$. A strip of flap over the cervico- mandibular groove coupled with Split skin graft on either side of this flap is also practised.This has the advantage that the healing graft stretches and pulls the flap which thus expands. This prevents the re-contracture but has a poor cosmetic appearance. 
Flaps including a free micro vascular have been used in many centers Various flaps used are cervicodorsal flap, parascapular flap, Acromial flap, latissimus dorsi, radial forearm, anterolateral thigh and groin flap. These have the advantage of a single staged procedure, avoidance of recurrence of contractures, wrinkling and prolonged splintage. The disadvantage is it requires a special setup and expertise to do the flap which are not always possible. In addition they are bulky and do not match the thin delicate skin of the neck. In the present series we have not used any flap Release of contracture and excision of scar tissue followed by surface cover with split thickness skin grafting has been the mainstay of treatment in 20 patients in this series.

A complete release was achieved by releasing all the scar tissues at the neck, mandible, face and pectoral region. The release had to cross the neutral line on either side of the neck before resurfacing.

The split skin grafts for neck contractures have been advocated from time immemorial by various authors Split skin graft as ordinarily used gives a disappointing result because of high incidence of postoperative contracture and wrinkling of the graft. These can be prevented by various splinting-pressure technique as advocated and confirmed by .We have used this combination of a medium sized split thickness skin graft and always accompanied by a pressure dressing and a splint. The longest follow up has been 2 years. The release has been maintained to 90 to 100 degrees and the graft appearance has been satisfactory. The degree of movement of the neck has been good postoperatively and has improved over days with rigorous Physiotherapy ·

\section{Summary And Conclusion:-}

1. Twenty patients with post burn scar contracture who underwent surgical correction were analyzed.

2. Complete release of the contracture, by scar excision, release incision, and designing local Z-plasties was obtained.

3. Resultant raw area was covered with Split thick skin graft (SSG) in 18 and with Full thickness graft FTG in 2 patients. FTG was selected as the defect was comparatively small and clean and the donor site (abdomen ) was lax.

4. The graft take was excellent with FTG, with high color and texture match

5. The graft take of Split thick skin graft, the color match and texture was equally good with 14 of the remaining patients.

6. Four patients had patchy graft loss which was re-grafted with stored graft in two and fresh SSG in the other two to obtain a good result.

7. A ready made cervical collar was used by all the twenty patients irrespective of the procedure. This splint was easily obtained from our splint-maker, inexpensive and had the highest patient compliance. Thus the release was maintained to full extent after 2,4,6 and 12 months.

8. The graft after 6 and 12 months was smooth, wrinkle-free, and supple.

9. The mento-cervical angle and the cosmetic appearance were very satisfactory. The movements of flexion, extension and lateral flexion, measured at the end of 6 months to one year after repair and splinting were very promising.

10. We did not have occasion to re-do surgery in any of our patients as none of them reported recurrence of contracture.

\section{References:-}

1. Angrigiani $\mathrm{C}$ Aesthetic micro surgical reconstruction of anterior neck burn deformities plastic reconstructive surgery.1994;93:507.

2. Boswick JAJr; burns of head and neck. Surg.clin. north Am 1973;53:97.

3. Bhattacharya S, Bhatnagar SK, Chandra R, Postburn contracture of the neck--our experience with a new dynamic extension splint. Burns. $1991 \mathrm{Feb}$;17(1):65-7.

4. Cope O, langohr JL. Moor Fd, etal. Expeditious care of full thickness burn wounds by surgical excision and grafting. Ann surg 1947;125:1-22.

5. Cole J, Engrav Lh, Heimbach DM, et al.Early excision and grafting of face and neck burns in patients over 20 years. Plastic. Reconstructive sur. 2002;109:1266-1273.

6. Cronin T. the use of a molded splint to prevent contracture after split skin grafting on the neck. Plas.recon.surg 1961:27:7.

7. Converse, J.M: Burns deformities of the face and neck, Reconstructive surgery and rehabilitation. Surg. Clin.North.Am, 47:323,1967. 
8. Cronin T.D. Successful Correction of extensive scar contracture of the neck using split skin grafts, In Skoog, T, and Ivy.R.H(Eds.): Transactions of the international society of Plastic Surgeons ( First Congress, 1955) Baltimore, Williams and Wilkins company, 1957,p.123

9. Cronin, T.D. Deformities of the cervical regeion,In Converse,J.M $\quad\left(\right.$ Ed), Reconstructive Plastic Surgery, $2^{\text {nd }}$ Edition,Philadelphia,W.A saunders company, 1977, p1643.

10. Cronin, T.D., The use of a molded splint to prevent contracture after a split skin grafting on the neck. Plastic Reconstr. Surg, 27.7,1961.

11. Davis J. the relaxation of scar contractures by means of the Z, or reversed Z- type incision * stressing the use of scar infiltrated tissues. Ann. sur 1931;94:871-884.

12. Donlean M, Silver man RP. Full thick ness skin grafts for elective facial burn reconstruction: review of 237 consecutive cases. J burn care rehabil 2002; 23(2):S68.

13. Dingman,R.O.: The Surgical treatment of Burns Scar Contracture of the Neck, Surg Clin North Am, $41: 1169,196$

14. FrackeletonW.H.:Neck Burns- Early and late Treatment In Skoog, T, and Ivy.R.H(Eds.): Transactions of the international society of Plastic Surgeons (First Congress, 1955) Baltimore, Williams and Wilkins company, 1957,p.130

15. Georger.C Crimshaw. A simple device to aid local immobilization, Department of Plastic Surgery, Kaiser Foundation Hospital, Oakland, California, USA

16. Grab WC. Basic techniques of plastic surgery in: grab WC and smith JW(editors), plastic surgery. Third edition 1979. Little, brown and company Boston P.P-3-74.

17. Gillies, H, Experience with tubed pedicle flaps. Surg.Gynaecol.obstet.,60:291,1935

18. GottilebE., Prolonged Postoperative cervical pressure as an adjunct to Plastic surgery of the neck,. Plastic Reconstr. Surg, 23;600,1963

19. Gilles H, Millard Dr Tr. The principles and art of plastic surgery. Boston: little, brown;1957.

20. Hari,K.,Torii.S.,Sekiguchi.J, The free lateral thoracic flap. Plastic Reconstr. Surg, 62;212,1978.

21. Harii,K., Ohmori,K and Ohmori.S.J: Utilization of free composite tissue transfer by micro vascular anastamosis for repair of Burn deformity, Burns, 1;237,1975.

22. Ho, L.C.Y Sykes, P.J., and Bailey, B.N.,: Extensive Deep Neck Burns< 1:149, 1975.

23. I.Kuran Treatment of a neck burn contracture with a super-thin occipito-cervico-dorsal flap: a case report, Burns, Volume 25, Issue 1, Pages 88-92

24. Jackson D, Topley E, cason JS, Etal primary excision and grafting of large burns. Ann sur 1960;152:167-189.

25. Janzekovic A.A new concept in early excision and immediate grafting burns . J.Trama 1970;10:1103-1108.

26. J. B. Lynch ${ }^{1}$, T. Ismael ${ }^{1}$, A. Saad ${ }^{1}$ and J. L. Kelly ${ }^{1,}$ Release of anterior neck burn contracture using artificial dermis and vacuum assisted closure - a case report, Irish journal of Medical sciences, Volume 174,page 71,supplement 1 march 2005

27. Jonsson CE, Dalsgaard CJ: early excision and skin grafting of selected burns of the face and neck plast.recon.sur.1991;88:83.

28. Kadry M., Hassan A., Tewfik 0., Ismail M Recent fasciocutaneous flaps for repair of post-burn neck, axillary and elbow contractures Plastic surgery Department, Faculty of Medicine, Cairo University, Egypt Medical Centre for Postgraduate Education in Warsaw and Hospital of Plastic Surgery in Polanica-Zdroj, Poland. 